\title{
Rare canine parasites survive in the wild fox population
}

\author{
Marja Isomursu*, Niina Salin, Antti Oksanen \\ From Parasite infections of domestic animals in the Nordic countries - emerging threats and challenges. \\ The 22nd Symposium of the Nordic Committee for Veterinary Scientific Cooperation (NKVet) \\ Helsinki, Finland. 7-9 September 2008
}

\section{Summary}

Members of the canid family - e.g. domestic dog Canis familiaris, wolf Canis lupus, red fox Vulpes vulpes and raccoon dog Nyctereutes procyonoides - share a wealth of parasite species. Nowadays, the diversity of the parasitic fauna of domestic dogs is reduced by antiparasitic medications and disposal of faeces, but a thriving population of wild foxes can host even rare parasite species. Finnish Food Safety Authority Evira, Fish and Wildlife Health Research Unit, examines approx. 250 fox carcasses for zoonoses every year. Some rarely seen canine endoparasites were observed in the winter 2007-2008.

In January 2008, one of the first Finnish domestic cases of Spirocerca sp. infection was observed in a fox hunted from North Lapland fjeld area in Utsjoki $\left(69^{\circ} \mathrm{N}\right.$ $27^{\circ} \mathrm{E}$ ). The previous one reported was imported from Tanzania [1]. A $30 \times 15 \mathrm{~mm}$ granuloma containing two large, red, coiled nematodes was formed on the curvatura major of the stomach. The fox was a male individual in good condition.

In a 1.5 year-old female fox from Pyhtää, Southeast Finland, a solitary female individual of French heartworm Angiostrongylus vasorum was lodged in the right ventricle, in the opening of the pulmonary artery. The existence of this parasite in Finland is very inadequately known, but it is spreading in Europe, e.g. in Denmark [2].

A massive liver fluke Metorchis albidus infection was observed in an aged (6.5 yrs) female fox from Virolahti, Southeast Finland. The flukes had caused a severe cholangitis. Although Metorchis is a very occasionally seen parasite in Finland, it is regarded as common in Germany [3].

Finnish Food safety Authority Evira, Fish and Wildlife Health Research Unit, Oulu, Finland
In addition to these isolated cases, a small survey of the occurrence of the bladder hairworm Capillaria plica was conducted in February 2008. Scrapings of urinary bladder wall were taken from 44 foxes from North Lapland and 7 of them (16\%) were positive for eggs or worms. In a Danish study, about $80 \%$ of foxes examined were found infected with this parasite [2]. All four parasite species mentioned above have at least one intermediate or paratenic host which may facilitate their persistence in the nature.

It is interesting to notice that a similar amount of raccoon dogs are also examined and comparable findings to the abovementioned have not been made. The raccoon dog often harbours higher Trichinella infection densities than the red fox does, and this has been speculated to be caused by some innate or acquired cause of immunoincompetence (unpublished). Therefore, raccoon dogs might be expected to harbour occasional parasite infections even more commonly than foxes.

\section{Published: 13 October 2010}

\section{References}

1. Nikander -S: Sukkulamadon (Spirocera lupi) aiheuttama osteosarkooma koiran ruokatorvessa. [Oesophageal osteosarcoma associated with Spirocerca lupi in a dog.]. Suomen Elainlaakarilehti. 1994, 100(3):173-177.

2. Saeed I, Maddox-Hyttel C, Monrad J, Kapel CMO: Helminths of red foxes (Vulpes vulpes) in Denmark. Veterinary Parasitology. 2006, 139(1/3):168-179.

3. Schuster R, Bonin J, Staubach C, Heidrich R: Liver fluke (Opisthorchiidae) findings in red foxes (Vulpes vulpes) in the eastern part of the Federal State Brandenburg, Germany - a contribution to the epidemiology of opisthorchiidosis, Parasitol. Res 1999, 85:142-146.

\section{doi:10.1186/1751-0147-52-S1-S22}

Cite this article as: Isomursu et al.: Rare canine parasites survive in the wild fox population. Acta Veterinaria Scandinavica 2010 52(Suppl 1):S22. 